\title{
Ovarian Torsion: Can We Operate Earlier?
}

\author{
Over Torsiyonu: \\ Daha Erken Opere Edilebilir miyiz?
}

\section{Ali AKDEMIR, ${ }^{a}$ Deniz ŞiMŞEK, ${ }^{a}$ Ahmet Mete ERGENOĞLU, ${ }^{a}$ Fatih ŞENDAĞ, ${ }^{a}$ Mehmet Kemal ÖZTEKINª}

${ }^{a}$ Department of Gynecology and Obstetrics, Ege University Faculty of Medicine, İzmir

Geliş Tarihi/Received: 19.08 .2014 Kabul Tarihi/Accepted: 13.03.2015

This study was presented as a poster at $23^{\text {rd }}$ Annual Congress of European Society for Gynaecological Endoscopy, 24-27 September 2014, Burssel.

Yazışma Adresi/Correspondence: Deniz ŞIMŞEK

Ege University Faculty of Medicine, Department of Gynecology and Obstetrics, İzmir,

TÜRKIYE/TURKEY

drdenizsimsek@hotmail.com

doi: 10.5336/gynobstet.2014-41571

Copyright $@ 2015$ by Türkiye Klinikleri

\begin{abstract}
Objective: To reduce the time period between emergency admission and operation, patients who were operated due to ovarian torsion, were evaluated in terms of clinical symptoms, diagnostic methods and treatment. We aimed to evaluate the management of the patient suspected ovarian torsion accompanied review of the literature. Material and Methods: Retrospective case review. Thirty-six patients who underwent laparoscopic ovarian torsion operation between 2010-2014 years were included in this study. Results: Surgically proved 36 cases of ovarian torsion were included in the study. The mean age of the patients was 27 years. Acute abdominal pain, vomiting and nausea were the main presenting symptoms. All the patients had abdominal tenderness and 13 of them (36\%) had positive peritoneal signs in abdominal examination. None of the patients had fever. Adnexal mass was detected in almost all patients in vaginal ultrasound. Transabdominal ovarian color Doppler duplex ultrasound imaging results were obtained 28 patients which were performed by radiology physician. From these, 14(50\%), 8(28\%) and 6(22\%) patients' ovarian duplex doppler imaging reported absent, decreased and normal blood flow respectively. Eight patients' doppler duplex ultrasound files were not able to find in the patients' file. All the patients underwent laparoscopic operation. Thirty of whom (83\%) treated conservatively and $6(16 \%)$ oophorectomy was performed. The median time interval from emergency service admission to operation was 9 hours and 20 minutes. This time period ranged 44 minutes and 25 hours 30 minutes. Conclusion: Ovarian torsion is hard to diagnose. The delay in diagnosis is the major obstacle for treatment. The biggest restriction is the lack of an appropriate imaging method or biochemical marker. To reduce the time between surgery and admission to the hospital, ovarian torsion diagnosis has to be preoccupied by any low abdominal pain synchronous with vomiting and detected abdominopelvic mass in bedside ultrasound. Laparoscopic conservative treatment should be considered as the first. To prevent the recurrence, cystectomy or adnexal fixation could be performed.
\end{abstract}

Key Words: Torsion abnormality; ultrasonography, doppler, duplex; laparoscopy

ÖZET Amaç: Acil servise başvuru ile operasyon arasındaki zamanı kısaltmak için, over torsiyonu nedeniyle opere olan hastalar klinik bulgu, tanı yöntemi ve tedavi şekilleri açısından değerlendirilmiştir. Over torsiyonu şüphesi olan hastaların yönetiminin, literatür eşliğinde değerlendirilmesi amaçlanmıştır. Gereç ve Yöntemler: Retrospektif vaka sunumu. 2010-2014 yılları arasında laparoskopik over torsiyonu cerrahisi yapılmış 36 hasta çalışmaya dahil edilmiştir. Bulgular: Cerrahi olarak kanıtlanmış 36 over torsiyonu vakası çalışmaya dahil edilmiştir. Hastaların ortalama yaşı 27 yıldır. Akut karın ağrısı, bulantı ve kusma ana semptomlardı. Batın muayenesinde, tüm hastalarda abdominal hassasiyet ve 13'ünde (\%36) pozitif peritoneal bulgular saptanmıştır. Hastaların hiçbirinde ateş yoktu. Adneksiyal kitle vajinal ultrasonda neredeyse tüm hastalarda tespit edildi. Radyoloji hekimi tarafindan bakısı yapılan, abdominal çift yönlü doppler ultrasonografi sonuçlarından 28 hastanın sonuçlarına ulaşıldı. Bunlardan, over doppler çift yönlü ultrasonografi sonucunda kan akımı saptanmayan, azalmış ve normal saptanan hasta sayıları sırasıyla 14 (\%50), 8 (\%28) ve 6 (\%22)'dir. Sekiz hastanın doppler çift yönlü ultrasonografi belgelerine ulaşılamamıştır. Bütün hastalar laparoskopik operasyona alınmışlardır. Bu hastalardan 30'una konservatif tedavi, 6'sına ooforektomi tedavisi uygulanmıştır. Acil servise kabul ile operasyon arasındaki zaman periyodu ortalama 9 saat 20 dakikadır. Bu zaman periyodu 44 dakika ile 25 saat 30 dakika arasında değişmekteydi. Sonuç: Over torsiyonunu teşhis etmek zordur. Tedavi için en büyük engel tanıdaki gecikmedir. En önemli eksiklik uygun bir görüntüleme yöntemi ve biyokimyasal bir belirtecin olmamasıdır. Hastaneye kabul ile operasyon arasındaki süreyi azaltmak için, alt karın ağrısı ile senkronize kusması olan ve yatak başı bakılan ultrasonografide abdominopelvik kitle saptanan hastalarda over torsiyon tanısı akılda tutulmalıdır. Laparoskopik konservatif tedavi öncelikli olarak uygulanmalıdır. Rekürrensi engellemek için kistektomi ve adneksal fiksasyon uygulanabilir.

Anahtar Kelimeler: Torsiyon anormalliği; ultrasonografi, doppler, çift yönlü; laparoskopi

Turkiye Klinikleri J Gynecol Obst 2015;25(2):86-91 


\section{A} dnexal torsion is partial or total rotation of adnexa around its vascular axis. Lymphatic and venous systems are primarily affected by this blockage, causes massive congestion of the ovarian parenchyma and hemorrhagic infarction. Next step is followed by arterial occlusion that leads to ischemia and eventually ovarian necrosis. ${ }^{1}$ It is the fifth most common cause of gynecological emergencies, with a prevalence of $2.7-3 \%{ }^{2}$ However this prevalence is probably underestimated because some patients are not operated and in some cases adnexa can spontaneously be detorsioned. Adnexal torsion primarily involves pathological adnexa. Torsion of normal ovaries occurs more commonly in young and adolescent girls than in women., ${ }^{2,3}$ Diagnosis is not easy because of the nonspecific signs, symptoms and limited benefits of the imaging techniques. Acute abdominal pain concomitant nausea and vomiting with positive peritoneal signs is the most important inkling for diagnosis. Asymmetry in ovarian size and the impairments of ovarian blood flow would endorse the diagnosis. Traditionally treatment of the ovarian torsion is oophorectomy because of the fear of thromboembolic phenomena or overlooking malignancy. However, no reported case of embolic incident after detorsion exists in literature. ${ }^{4}$ Immediate intervention is obligatory after ovarian torsion diagnosis. Laparotomy or laparoscopy can be performed for treatment. ${ }^{5}$ Delayed treatment inevitably causes ovarian necrosis. More recently laparoscopic management has been proposed.

We aimed to evaluate the factors postpone ovarian torsion treatment and propose the solutions for precipitous diagnosis and treatment.

\section{MATERIAL AND METHODS}

We retrospectively evaluated laparoscopic proved ovarian torsion patients between January 2010 and March 2014 at Ege University School of Medicine, Department of Obstetrics and Gynecology. During this period 36 patients underwent laparoscopic surgery. Patients' characteristics, symptoms and signs, clinical and physical examination findings, diagnostic methods, laboratory findings, time intervals between emergency room admission to operation, surgical findings, mode of treatment and pathologic results were retrospectively reviewed.

Transvaginal ultrasound examination was performed by $6.5-\mathrm{MHz}$ vaginal probe. Abdominal doppler duplex ultrasonography examination was performed by 3.5-Mhz abdominal probe. Doppler duplex ultrasonography was performed by radiologist via abdominal probe. Transvaginal ultrasound was performed by gynecologists.

Preoperative informed consent was obtained from each patient.

\section{RESULTS}

Thirty six adnexal torsion patients underwent laparoscopic operation over a four years period. The mean age was $27 \pm 7,4$ (range: $18-49$ ) years. Number of the patients aged over 35 and the pregnant patients was $5(13 \%)$ and $3(8 \%)$ respectively. Four (11\%) patients had ovarian stimulation treatment history with gonadotropins, 2 of whom were pregnant.

Acute abdominal pain was the constant sign (100\%). Twenty-three patients (63\%) experienced abrupt onset pain and the rest had gradual onset pain. Twenty-eight patients experienced nausea and vomiting with a rate of $77 \%$. At physical examination all patients had considerable lower abdominal or pelvic tenderness, although peritoneal irritation signs, such as rebound tenderness and guarding, were present in 13 patients (36\%). None of the patients had fever more than $38,3^{\circ} \mathrm{C}$. Neither blood nor urine laboratory analysis did provide significant benefit to facilitate the diagnosis. Hyperleukocytosis and elevated C-reactive protein detected in 13 and 8 patients, respectively. Demographic data, symptoms and signs were summarized in Table 1.

Preoperative transvaginal ultrasound and abdominal doppler ultrasound were performed in all patients although 28 of the patients abdominal doppler blood flow performance were obtained. Transvaginal ultrasound exposed pelvic mass in almost all patients. Only 2 patients had normally sized ovary. Asymmetry enlarged, edematous and small cystic structures around the periphery of the ovary detected in all patients. Thirty patients had enlarged $(5-10 \mathrm{~cm})$ and 4 patients who utilized go- 


\begin{tabular}{|lcll|}
\hline & TABLE 1: Demographic data, symptoms, signs. & \\
\hline Characteristics & Number of patients & Total & Ratio \\
Mean Age (year) & $27 \pm 7.4$ & $18-35$ years: 31 & $87 \%$ \\
& & $>35$ years: 5 & $13 \%$ \\
Pain & 36 & Abrupt onset: 23 & $63 \%$ \\
& & Gradual onset: 13 & $36 \%$ \\
Pain localization & & Right lower quadrant: 14 & $38 \%$ \\
& & Left lower quadrant: 11 & $30 \%$ \\
& & Diffuse: 3 & $8 \%$ \\
Nausea, Vomiting & Lower quadrant: 8 & $22 \%$ \\
Abdominal Tenderness & 28 & & $77 \%$ \\
Peritoneal signs & 23 & & $63 \%$ \\
Fever & 13 & $36 \%$ \\
\hline Hyperleukocytosis & 0 & & $36 \%$ \\
Elevated C-reactive protein & 13 & & $22 \%$ \\
\hline
\end{tabular}

nadotropins treatment had ovaries more than 10 $\mathrm{cm}$. No blood flow detected in 14 patients (50\%) and decreased blood flow detected in 8 patients and 6 patients had normal blood flow. Eight patients' Doppler duplex ultrasound files were missing. U1trasound findings were summarized in Table 2.

Laparoscopic surgery was performed in all patients. Sixty-one percent of the torsions (n:22) were on the right side. The degree of the torsions ranged from $360^{\circ}$ to $1440^{\circ}$ and the median torsion rate was $720^{\circ}$. Conservative surgical treatment was performed in 30 cases, however, oophorectomy was performed in 6 cases. Table 3 depicts the details of the surgical treatment.

No complication was occurred during the operation and post-operative time. Patients were discharged on postoperative day 1 . Two pregnant women had birth at term yet, one patient had stillbirth in $33^{\text {rd }}$ week. No trombo-embolic complication secondary to detorsion occurred in patients treated conservatively.

When we evaluated the time duration between admission to the emergency service and operation room, it ranged from 44 minutes to 25 hours and 30 minutes with a mean interval of 9 hours and 20 minutes.

Summary of pathology results were shown in Table 4.

\begin{tabular}{|llcc|}
\hline \multicolumn{3}{|c|}{ TABLE 2: } & Ultrasound findings. \\
\hline \multirow{3}{*}{ Ovary localization } & Characteristics & Number & Ratio \\
& Right & 22 & $61 \%$ \\
Ovary size & Left & 14 & $39 \%$ \\
& $<5$ & 2 & $5.5 \%$ \\
& $5-10 \mathrm{~cm}$ & 30 & $83.3 \%$ \\
& $>10 \mathrm{~cm}$ & 4 & $11.1 \%$ \\
Doppler Blood Flow $(\mathrm{n}: 28)$ & Normal & 6 & $21 \%$ \\
& Decreased & 8 & $28 \%$ \\
& Absent & 14 & $50 \%$ \\
\hline
\end{tabular}

\begin{tabular}{|lcc|}
\hline \multicolumn{3}{|c|}{ TABLE 3: Surgical treatment. } \\
\hline Surgical intervention & Number & Ratio \\
Only Detorsion & 11 & $30 \%$ \\
Detorsion with cyst drainage & 3 & $8 \%$ \\
Detorsion with cystectomy & 13 & $36 \%$ \\
Detorsion with oophoropexy & 3 & $3 \%$ \\
Oophorectomy & 6 & $16 \%$ \\
\hline
\end{tabular}

No malign lesions determined among the 19 lesion that examined by pathology.

\section{DISCUSSION}

Our article is one of the unique study that investigates time that lapses from presentation to hospital to operation. We aimed to find out the obstacles delay the treatment and eliminate these obstacles. 


\begin{tabular}{|c|c|c|}
\hline Characteristics & Number & Ratio \\
\hline Simple cyst & 6 & $31 \%$ \\
\hline Serous cystadenoma & 4 & $21 \%$ \\
\hline Dermoid & 3 & $15 \%$ \\
\hline Paratubal cyst & 3 & $15 \%$ \\
\hline Normal ovary tissue & 2 & $10 \%$ \\
\hline Endometriosis & 1 & $5 \%$ \\
\hline Total & 19 & \\
\hline
\end{tabular}

Ovarian torsion is a rare but true gynecologic emergency which should be operated immediately. It is the fifth most common cause of gynecological emergencies but tends to rise as iatrogenic because of the increased infertility treatment. The incidence rises dramatically to $6 \%$ after ovarian stimulation and reaches as high as $16 \%$ in cases of ovarian hyperstimulation. It is estimated that $12-25 \%$ of women with torsion are pregnant. ${ }^{6,7}$ In our study 3 patients (8\%) were pregnant and 4 patients $(11 \%)$ had a history of ovarian hyperstimulation. These all 4 patients' ovarian size was more than $10 \mathrm{~cm}$.

Diagnosis of the adnexal torsion especially in pregnant women is quite difficult. The symptoms are acute abdominal pain, nausea/vomiting and adnexal mass. Yet, none of these symptoms are specific for adnexal torsion and can be confused with a wide variety of other abdominal disease processes. There are some ovarian torsion case series comparing the symptoms, risk factors and treatment modalities of pregnant and non-pregnant women in literature. ${ }^{2,8,9}$ These studies have emphasized that there is no significant difference between pregnant and non-pregnant women in the symptoms and the ultrasound view. Fertility treatment is the leading risk factor of ovarian torsion. Although risk factors for ovarian torsion was not assessed in the present study, 4 patients had a history of infertility treatment and this is consistent with the literature.

Ultrasound (US) is the first and the most useful method for imaging the adnexa. However, no specific US finding has been described for ovarian torsion. Ultrasound examinations of the patients with ovarian torsion usually demonstrate enlarged, cys- tic, and sometimes edematous ovaries with the small cystic structures around the periphery of the ovary. Benign ovarian cysts especially simple cysts and dermoid cyst are the most frequent while endometriosis is the rarest pathology. Computed tomography imaging (CT) and magnetic resonance imaging (MRI) can also give important information but they are expensive and sometimes it can cause loss of time. In a recent article authors compared US, CT and MRI for diagnosis ovarian torsion. MRI and CT were useful to show decreased contrast enhancement and adnexal fat stranding but they had not enough for certain diagnosis. ${ }^{10}$ On the other hand, in another study, the diagnostic value of initial CT was found less beneficial than initial sonography. ${ }^{11}$

The use of Doppler flow analysis on ultrasound can help to improve diagnostic accuracy but it has a high false-negative rate. ${ }^{12}$ Doppler blood flow including color and power doppler measurements can support the diagnosis of ovarian torsion yet, these techniques should not be preferred to exclude ovarian torsion diagnosis. ${ }^{7,13,14}$ Vijayaraghavan described a new ultrasound imaging for ovarian torsion called the whirlpool sign. ${ }^{13}$ It is similar to the whirlpool sign described with caudal movement of the probe in malrotation of the midgut with volvulus. Wherein during sonography the probe is moved to and fro along the central axis of the twisted pedicle, the whirlpool sign is seen as a hypoechoic band representing the vessels wrapping around the central axis. Vijayaraghavan reported all the patients determined whirlpool sign had ovarian torsion. ${ }^{13}$ However, in present study abdominal doppler ultrasound was performed by radiology physician and they did not reported whirlpool sign. Nevertheless the whirlpool sign can be seen accurately by transvaginal doppler examination. Thus, we had no any consideration whether whirlpool sign exist in our cases.

Once the diagnosis of ovarian torsion is suspected or confirmed due to clinical findings and imagining methods, immediate intervention is necessary. ${ }^{15-23}$ Laparoscopy allows the definite diagnosis of adnexal torsion as a first. ${ }^{24-26}$ With similar to recommendation in the literature all cases was operated with laparoscopy in the present study. 
Ovarian torsion is slightly more common on the right side as in our case serial. Physiologically the right utero-ovarian ligament is longer than the left side, besides, sigmoid colon is a constant organ than distal ileum and cecum that effect ovarian instability. Thus, right ovarian torsion is more common than left side. ${ }^{2,9}$ During the surgery, black bluish appearance of the torsioned ovary can be alerting which can lead surgeon to perform oophorectomy due to fear of thromboembolism. However no trombo-embolic complication secondary to detorsion was noted in literature. Similarly, in our patients no trombo-embolic complication secondary to detorsion occurred. Solely adnexal detorsion is enough in most of the cases. After detorsion surgeon should decide whether oophorectomy or conservative treatment. The ability to predict adnexal viability is difficult in many instances. In our clinic, we wait for 20 minutes after detorsion. If the color of the ovary shows alteration of viability such as getting pink or red, we do not perform oophorectomy but if it still seems necrotic or non-viable then we perform oophorectomy treatment. In literature some authors decided to use intravenous fluorescein and then observe the untwisted adnexa under ultraviolet light to predict the viability. ${ }^{15}$

Mode of treatment can also be considered by surgical consideration such as friability of the tissue could limit cystectomy or fixation. In pregnant patients detorsion and cyst fenestration are the mostly performed operation choice to shorten the duration of surgery. ${ }^{8}$ To prevent the recurrence rate of torsion, if cystectomy cannot be achieved, serious consideration should be given to perform adnexal fixation which can be achieved through shortening of the utero-ovarian ligament by means of a shortening suture, ring, or clip thus approximating the ovary to the uterus and preventing future torsion. ${ }^{16}$

In literature, there are many case reports mentioned ultrasound guided cyst aspiration via transabdominal or transvaginal as a new method for conservative management of adnexal torsion especially in patients with ovarian hyperstimulation. ${ }^{17,18}$
Progesterone supplement therapy is important for pregnant patients to decrease abortion rates. All of the pregnant patients had progesterone treatment postoperatively in the present study. Two of three pregnant patients delivered at term but one patient had stillbirth at $33^{\text {th }}$ week.

The pain usually develops over a short period of time, from a few hours to less than two days. ${ }^{19}$ Pain lasting more than $10 \mathrm{~h}$ before surgery is associated with an increased rate of adnexal necrosis. ${ }^{20}$ In present study, the median time interval from emergency room admission to operation room was 9 hours and 20 minutes. In the literature, the time duration between onset of pain and the surgery was ranged 6 hours to 13 days. ${ }^{21-23}$ We could not have clear information about the starting time of the pain. Nevertheless, 9 hours seems to be a long time for diagnosis in emergency service. Viability of ovary tissue depends on the severity of torsion, tissue durability to ischemia and the time between pain and detorsion. Each patient should be questioned in detail whether they had pathological adnexal mass in patient history, infertility treatment history, previous ovarian torsion operation. Abdominal examination provides the most important information in understanding whether patients need surgery. The next step should be bedside ultrasound examination by emergency physician. If asymmetry in ovarian size, adnexal mass or hyperstimulated ovaries are detected, gynecological consultation should be quickly requested. Doppler ultrasound examination, CT or MRI could give important information about ovarian torsion but the most important point is the clinical suspicion and the patient's condition. If all patients are evaluated by emergency physician, general surgeon, gynecologist and radiologist physicians at the bedside, the operation time undoubtedly will be reduced.

As conclusion, we presented our ovarian torsion patients' data to acquire the precipitous diagnosis. Anamnesis and the serial ultrasound examination would facilitate the diagnosis. $\mathrm{Pa}$ tient's clinical and physical examination is the most precious findings for diagnosis. Laparoscopic conservative surgery should be the first choice however, it should be noted surgeons should choice the operation technique via their experience. 


\section{REFERENCES}

1. Graif M, Itzchak Y. Sonographic evaluation of ovarian torsion in childhood and adolescence. AJR Am J Roentgenol 1988;150(3):647-9.

2. Hibbard LT. Adnexal torsion. Am J Obstet Gynecol 1985;152(4):456-61.

3. Berger RL, Robbins G. Torsion of the normal ovary. Am J Surg 1961;102:716-9.

4. Sommerville M, Grimes DA, Koonings PP. Campbell K. Ovarian neoplasms and the risk of adnexal torsion. Am J Obstet Gynecol 1991; 164(2):577-8.

5. Meynol F, Steyaert H, Valla JS. Adnexal torsion in children: plea for early laparoscopic diagnosis and treatment. Arch Pediatr 1997; 4(5):416-9.

6. Rackow B, Patrizio P. Successful pregnancy complicated by early and late adnexal torsion after in vitro fertilization. Fertil Steril 2007; 87(3):697.e9-12.

7. Mashiach S, Bider D, Moran O, Goldenberg M, Ben-Rafael Z. Adnexal torsion of hyperstimulated ovaries in pregnancies after gonadotropin therapy. Fertil Steril 1990;53(1): 76-80.

8. Hasson J, Tsafrir Z, Azem F, Bar-On S, Almog B, Mashiach R, et al. Comparison of adnexal torsion between pregnant and nonpregnant women. Am J Obstet Gynecol 2010;202(6): 536.e1-6.

9. Smorgick N, Pansky M, Feingold M, Herman A, Halperin R, Maymon R. The clinical characteristics and sonographic findings of maternal ovarian torsion in pregnancy. Fertil Steril 2009;92(6):1983-7.
10. Lourenco AP, Swenson D, Tubbs RJ, Lazarus E. Ovarian and tubal torsion: imaging findings on US, CT, and MRI. Emerg Radiol 2014; 21(2):179-87.

11. Chiou SY, Lev-Toaff AS, Masuda E, Feld RI, Bergin D. Adnexal torsion: new clinical and imaging observations by sonography, computed tomography, and magnetic resonance imaging. J Ultrasound Med 2007;26(10):1289301.

12. Naiditch JA, Barsness KA. The positive and negative predictive value of transabdominal color Doppler ultrasound for diagnosing ovarian torsion in pediatric patients. J Pediatr Surg 2013;48(6):1283-7.

13. Vijayaraghavan SB. Sonographic whirlpool sign in ovarian torsion. J Ultrasound Med 2004;23(12):1643-9.

14. Yaman C, Ebner T, Jesacher K. Three-dimensional power Doppler in the diagnosis of ovarian torsion. Ultrasound Obstet Gynecol 2002;20(5):513-5.

15. McHutchinson LL, Koonings PP, Ballard CA, d'Ablaing $G$ 3rd. Preservation of ovarian tissue in adnexal torsion with fluorescein. Am J Obstet Gynecol 1993;168(5):1386-8.

16. Weitzman VN, DiLuigi AJ, Maier DB, Nulsen JC. Prevention of recurrent adnexal torsion. Fertil Steril 2008;90(5):2018.e1-3.

17. Boswell KM, Silverberg KM. Recurrence of ovarian torsion in a multiple pregnancy: conservative management via transabdominal ultrasound-guided ovarian cyst aspiration. Fertil Steril 2010;94(5):1910.e1-3.
18. Chang EM, Kim A, Kim JW, Yoon TK. Ultrasound-guided transvaginal aspiration as initial treatment for adnexal torsion following ovarian hyperstimulation. Eur J Obstet Gynecol Reprod Biol 2010;152(1):60-3.

19. Lomano JM, Trelford JD, Ullery JC. Torsion of the uterine adnexa causing an acute abdomen. Obstet Gynecol 1970;35(2):221-5.

20. Mazouni C, Bretelle F, Ménard JP, Blanc B, Gamerre M. [Diagnosis of adnexal torsion and predictive factors of adnexal necrosis]. Gynecol Obstet Fertil 2005;33(3):102-6.

21. Celik A, Ergün O, Aldemir H, Ozcan C, Ozok G, Erdener A, et al. Long-term results of conservative management of adnexal torsion in children. J Pediatr Surg 2005;40(4):704-8.

22. Aziz D, Davis V, Allen L, Langer JC. Ovarian torsion in children: is oophorectomy necessary? J Pediatr Surg 2004;39(5):750-3.

23. Galinier $P$, Carfagna L, Delsol M, Ballouhey $Q$, Lemasson $F$, Le Mandat $A$, et al. Ovarian torsion: Management and ovarian prognosis: a report of 45 cases. J Pediatr Surg 2009; 44(9):1759-65.

24. Huchon C, Fauconnier A. Adnexal torsion: a literature review. Eur J Obstet Gynecol Reprod Biol 2010;150(1):8-12.

25. Oelsner G, Shashar D. Adnexal torsion. Clin Obstet Gynecol 2006;49(3):459-63.

26. Mage G, Canis M, Mahnes H, Pouly JL, Bruhat MA. Laparoscopic management of adnexal torsion. A review of 35 cases. J Reprod Med 1989;34(8):520-4. 